\title{
Overcoming theological voicelessness in the new millennium
}

\section{J.N.J. (Klippies) Kritzinger ${ }^{1}$}

\begin{abstract}
This opening paper of the Voicelessness conference in October 2011 gives an introduction to the theme. After tracing the semantic fields in which "voicelessness" is used, the paper develops a "phenomenology" of the concept. Seven types of voicelessness are identified and applied to theological voicelessness. The periodisation implied in "the new millennium" is also explored, before reflecting on the theological method needed to face these challenges. The paper concludes by proposing five ways of overcoming theological voicelessness. These involve developing new strategies in relation to identity, research, politics, the academy, and worship.
\end{abstract}

Keywords: Voicelessness, new millennium, theological method, praxis, nepotism, apathy, inferiority, identity strategies.

\section{Introduction}

The title of my paper contains at least three assumptions. The first is that theologians are experiencing voicelessness; the second is that this experience is bad, and therefore needs to be overcome; and finally it is assumed that the new millennium has something to do with it; that this is a new challenge, or at least that recent developments are making the situation worse, or more urgent. Let me explore these three assumptions at the outset to clarify my approach to the topic.

\subsection{Voicelessness}

Voicelessness is an unusual term. It is not quite the same as silence because silence can have a positive connotation, as in meditation and contemplative prayer. Voicelessness, on the other hand, seems to have an inherently negative ring to it, having probably been modelled on an expression like homelessness. To describe a person as non-white or illiterate or homeless is to talk about someone in terms of what she is not, rather than in terms of what (or who) she is. Similarly, it is not a neutral, but an inherently negative description to talk of voicelessness. When theology and (by implication) theologians are assumed to be voiceless in the title of this paper, that is seen as negative, as problematic. After all, what is a theology or a theologian without a voice? An intriguing set of assumptions underlie this way of thinking, which could take some time to analyse. I will not do that now; those assumptions will surface in the course of my paper.

1 Prof. J.N.J. (Klippies) Kritzinger teaches missiology at the University of South Africa. He can be contacted at kritzjnj@unisa.ac.za. 


\subsubsection{Semantic fields}

What I want to do first is look at the semantic fields in which this term is most frequently used. Broadly speaking, dictionaries identify three semantic fields in which "voicelessness" is used: $(a)$ speech and language pathology: a disorder of the vocal organs that results in loss of voice (synonym: aphonia); (b) speaking softly without vibration of the vocal cords (synonym: whisper); $(c)$ having no voice in the management or control of affairs, for example "the voicelessness of those who live in situations of hopelessness" (synonyms: impotence, powerlessness). ${ }^{2}$ It is clearly in this last sense that we are using "voicelessness" in our conference; it is about not having a say, about feeling (and being) powerless and marginalised. It is therefore fundamentally a question of power and influence. And it is important to remember that power is not a "thing": "Power is not an 'entity' but a way of interacting. Power is not an 'entity' but a way of interacting. Power points to something that happens between people" (Whitehead and Whitehead 1984:152).

\subsubsection{A phenomenology of voicelessness}

It may be helpful at this point to offer a brief "phenomenology of voicelessness", ${ }^{3}$ to explore the dynamics of the power play involved, before looking specifically at theological voicelessness. How is it that people become (or are made) voiceless in society? I suggest that there are at least seven reasons for voicelessness (or types of voicelessness):

(a) Voicelessnesss as a result of shock, for example when someone is confronted with a deep personal tragedy like the death of a close relative or friend:

I sat up in bed in stunned silence. What could I say? The little girl whom I had watched grow from a baby to a toddler and into a lively, vibrant child was gone. All that remained was devastation, sadness, and the question why? (Swinton 2006:9).

"What could I say?" This phrase expresses voicelessness in the face of unexpected and inexplicable tragedy and loss. It is a shocked silence when faced with death and suffering that we regard as unfair and unmerited, which Farley (1990) has called "radical" suffering. We can become voiceless when the suffering of others overwhelms us and stuns us into silence.

(b) Voicelessness as a result of inferiority, for example when someone remains quiet in a conversation because she or he does not want to make a fool of herself or himself among people whom she or he regards as more informed or more powerful. Closely related to this is a feeling of relative ignorance, a sense of being overwhelmed by the complexity or enormity of

2 These three uses of the term were taken from Farlex (n.d.).

3 I follow the example of Miroslav Volf (1996) here. He developed a "phenomenology of embrace", which started with drawing attention to its "essential structural elements" (p. $140 \mathrm{ff})$. 
an issue. Sometimes such a sense of inferiority comes from having been bullied into silence by a dominant group, thus giving rise to a "culture of silence" (Freire). ${ }^{4}$ We can become voiceless when the power and influence of others intimidate us into silence.

(c) Voicelessness as a result of guilt, for example when people do not say anything in a group because they feel ashamed of their former actions. In their own minds, they lack the credibility to say anything in public about the particular issue. This often flows from a sense of failure and a loss of nerve. We can become voiceless when the mere presence of others reminds us of our wrongdoing in the past, and thus we censor ourselves into silence.

(d) Voicelessness as a result of apathy, for example when people switch television channels when images of famine in Somalia appear. Often we do not want to say anything, or even discuss it, because we do not want our comfort zones to be disturbed. We are busy (very busy) with other priorities, and are not willing or able to devote any energy to this issue. This form of voicelessness is often justified from a sense of specialisation: that issue is not in my area of expertise; I am specialised in something else. We can become voiceless when we do not allow the plight of others to disturb our comfort and our priorities, and we choose the silence of evasion.

(e) Voicelessness as a result of friendship, for example when we fail to publicly expose or criticise a particular instance of corruption because the people committing it (or their superiors who are responsible) are our friends or relatives. In such cases, we do not make public statements; if we do anything at all, we make appointments with our friends and speak to them in the privacy of their offices because we do not want to embarrass them publicly. After all, they are "our people". We can become voiceless when we allow ties of family and friendship to mute our prophetic voice into a complicit and nepotistic silence.

$(f)$ Voicelessness as a result of a specific world-view, for example when believers assert that a particular matter is a political or economic issue and that they are called to be spiritual and must thus work on religious issues in a religious way. We can become voiceless when we reduce our faith to something interior or heavenly, thus opting for a reductionist spiritual silence.

( $g$ ) Voicelessness as a result of awe and admiration, for example when someone sits quietly and drinks in the beauty of the night sky, of a majestic mountain range, of a newborn baby, or of a painting. This is not a negative silence, but a positive appreciation of beauty. Not all power is oppressive; there are impressive, attractive and therapeutic forms of power. As

4 This Freirean concept refers to an imposed silence, which "does not signify an absence of response, but rather a response which lacks a critical quality. Oppressed people internalize negative images of themselves (images created and imposed by the oppressor) and feel incapable of self-governance." (quoted from "Glossary of some Freirean Terms" in McLaren http://www.gseis.ucla.edu/ mclaren/ - accessed 26 November). 
Whitehead and Whitehead (1984:152) have said, in response to the well-known saying of Lord Acton ("Power tends to corrupt, and absolute power corrupts absolutely."): "Power tends to heal, and absolute power heals absolutely." We can become voiceless when we are overwhelmed by the beauty and the healing power of love.

It is clear that these seven reasons for voicelessness (or types of voicelessness) that I have constructed are not mutually exclusive. They are also not all negative, as I suggested in the beginning, nor do they exhaust all possible types of voicelessness. But I hope they chart the terrain of this conference in some helpful way at the beginning of our deliberations. What is clear from this little typology is that voicelessness is usually a particular way of exercising power or refusing to exercise power, and therefore a conscious choice. It can, however, also be an absence of choice, a silence enforced on one by others.

\subsection{Theological voicelessness}

This term suggests that theologians have become (or are becoming) voiceless, that their voices are not (or no longer) being heard. The question is in what sense that is true. Ostensibly, theologians are still quite talkative. Publishers in South Africa and worldwide produce theological books at a rapid rate; theological journals continue to operate and new ones appear at regular intervals. In South Africa, there has even been the perception that there are too many accredited theological journals, creating a situation that allows theologians to receive more than their due share of the national research output cake. As a result, the Academy of Science of South Africa is doing an audit of theological (and other) journals, to check whether all of them comply with research standards that would justify the output subsidies paid to South African universities on the basis of the articles published in them. In some respects, therefore, theologians are (still) making their voices heard. But the emphasis of our conference is not on research publications. In the call for papers, the organisers invited us to present papers on the basis of the following rationale:

During the apartheid era theologians made a major contribution to the establishment of a new society based on e.g. the virtues of justice and mutual respect. Today it would seem that theology is no longer respected in the public domain [nor is it] as active as it should be. It is the task of theologians to see that their work once again becomes acceptable as a credible science that is needed in the moral and indeed spiritual formation of a new society (Unisa 2011).

We are gathered here, then, to reflect on the public voicelessness of theologians in South Africa-and (perhaps) in other countries. The programme indicates that speakers from various countries will analyse the particular kinds of theological voicelessness prevalent in their contexts. I 
find it important to stress that the motivation of the organisers in calling this conference was not a nostalgic desire to return to a dominant power position that theology occupied in an idealised past. In fact, the former "power" of theology to which the organisers refer was, paradoxically, often exercised from positions of social weakness and marginalisation, often even from positions of banning, imprisonment, torture and exile. In the struggle for liberation and democracy, particular forms of theology were indeed influential and widely respected in oppressed and suffering communities, and a significant number of theologians were influential public voices in South African society. At the time, they were often perceived and respected as spokespersons of voiceless and powerless communities. Yet they were often lone and isolated "voices crying in the wilderness" that were called "abrahamic minorities" by Dom Hélder Câmara (2012 [1972]:3):

The Spirit of God raises them up deep within every race, in every religion, every nation, every human group. Who belongs to these abrahamic minorities? All those who, like Abraham, hope against hope and decide to work to the point of sacrifice for a more just and humane world.

Such creative and uncomfortable minorities were often frowned upon as "troublemakers" by the institutional churches - and yet they kept alive the prophetic tradition down the centuries within the Christian movement. It is painful to admit that many South African theologians (many of us, therefore) have been reluctant to raise our voices publicly on certain issues since 1994. I wish to trace some of the reasons for this voicelessness:

(a) The "normalisation" of our society into a democracy, in which religious leaders do not need to "stand in" for political leaders who are in prison or in exile, is one reason. This has led to the view that religious leaders can return to their proper business of preaching and counselling, while the politicians take over the running of public affairs. This "world-view voicelessness", as I called it above, is a significant strand in our present theological voicelessness.

(b) The growing "modernisation" of our society, which has led to greater individualism and rationalism in the white and black middle class, has caused the separation between facts (that are public and "scientific") and values or beliefs (that are private and a matter of taste). Missiologists like Newbigin (1984; 1986; 1989:64f) and Bosch $(1991 ; 1995)$ have analysed this feature of modernity in depth and pointed out its negative effects on Christian public witness. It gives rise to "inferiority voicelessness" (as I called it) among theologians who have no background in the natural sciences and are too intimidated by scientific "facts" and "experts" to open their mouths in public. The growing stridency of 
atheist apologists like Richard Dawkins (2006) and Christopher Hitchens, and popular books like the Da Vinci code (Brown 2003), have put many Christians on the back foot and effectively silenced them in the public square.

(c) The role played by the print and electronic media in South Africa should also be considered. Largely, religion is no longer as newsworthy as it was when the political system of apartheid was defended theologically and theology was therefore a key "site of struggle". As obvious as it was then that the abbreviation "DRC" in an English newspaper referred to the Dutch Reformed Church, just as obviously today it refers to the Democratic Republic of Congo. The media creates its "media darlings" and in the past decade those darlings have been theologians or church leaders increasingly less often. This is also a form of "inferiority voicelessness", but an inferiority or irrelevancy imposed on theologians by journalists and editors. The views of theologians on public matters are often not regarded as helpful or enlightening.

(d) The former theological support of apartheid by DRC theologians and the widespread sex abuse scandals in the Catholic Church have also played a role. It has brought about a voicelessness of guilt and shame among some theologians. Afrikaner theologians seem to be afraid of being branded racists if they publicly criticise government policy or practice. The general decline in membership of "mainline" churches (black and white) also contributes to a loss of nerve and sense of hesitancy among theologians to make public pronouncements.

(e) Another growing phenomenon seems to be "apathy voicelessness" among theologians who despair of being able to make a difference, and therefore withdraw into a cocoon, resigning themselves to the "fact" that there is nothing they can do to improve the situation in the country or the continent. Such Afro-pessimism is evident among both the poor and the middle classes. It is also found among theologians.

(f) Finally, there is a "nepotistic" voicelessness (to which I referred above), caused by our hesitation to publicly criticise leaders who are members of our families or congregations. It is more important for us to retain them as members (for the money they contribute to the church coffers) or to be photographed with them than to prophetically expose their failures of policy and service delivery.

The organisers of this conference, in their call for papers, pointed out that the "virtues of justice and mutual respect"- towards which theologians made such a contribution in the past-seem to have dropped off the theological agenda, at a time when these virtues have not yet been firmly 
entrenched in South African society. They have invited us to examine the nature and causes of our present theological voicelessness, and to re-commit ourselves to a theology that is a relevant and credible academic discipline with a clear public voice. For this we need to thank them sincerely.

\subsection{In the new millennium}

As human societies, we have a need for periodisation, for marking historical milestones that distinguish epochs or eras from each other. It is questionable how useful these markers of time and development really are because the significant turning points or defining moments in a society's collective existence - the kairos moments - very seldom coincide with the chronos moments of our watches or calendars. The question is: has the dawning of the third millennium of our Common Era had a significant impact on theologians in South Africa and their voice or voicelessness? Speaking from a global perspective, we could say that the new millennium dawned in 1989, with the falling of the Berlin Wall, which meant the official end of the Cold War and (for many people across the world) the end of the credibility of communism and socialism. In the United States, someone called it the "end of history" (Fukuyama 1992). It certainly changed the world as we knew it. It took away the last excuse of the communist threat to Christianity and civilisation that the apartheid government used to ban the liberation movements in South Africa and to continue its widespread destabilisation of neighbouring Southern African countries. The influence of the Berlin Wall was so great that it was called simply "The Wall" because it literally divided humanity between the First World and the Second World, thus giving rise also to the Third World, where power games and proxy wars were fought between the First World and the Second World.

In this introductory paper to the conference, I cannot go deeply into all the issues raised by the wide-ranging topic of our conference, but I wish to signal the need for thoroughgoing context analysis as a prerequisite for finding a new theological voice for the years ahead. What exactly happened between 1989 and 1994 in South Africa? What was the precise nature of our political transition to democracy? What happened to the South African economy in that process? It may be that our theological voices are so muted today because we are not sure of precisely what has happened - and what is happening - around us. Or are we reluctant to admit what is becoming clearer by the day, namely that the ANC - in its transformation from liberation movement to ruling political party-has made enormous compromises with the existing economic powermongers in South Africa. How we interpret these compromises is what matters theologically. There are those who would argue that it represented a "miraculous" transition from a racist oligarchy to a non-racial democracy and that the compromises that were made on the ownership of land and the means of production were 
necessary to avoid bloodshed, thus serving the interest of reconciliation. Others contend that the compromises made in the process of "elite pacting" between the former white captains of industry and the newly affirmed black elite have proven to be fatal to a large majority of black South Africans, who still live in squalor and do not see their lives improving (see for example Van der Westhuizen 2007).

This whole range of issues is implied in the phrase "in the new millennium". In this paper, I am not able to give a detailed analysis of the South African context, with its cultural, social, legal, political and economic dimensions, and say something about overcoming voicelessness. The topic is simply too vast for that. I am going to limit myself to a brief analysis of what is happening at South African universities with the teaching of theology and religious studies, with a focus on the University of South Africa. Before doing that, I need to take a step backwards and address the question of theological method. I do this because I believe that this is central to the process of finding a new theological voice (or voices) in this fast-changing context.

\section{Refining our theological method}

If our public theological voice in the new millennium is to avoid the temptations of sycophancy (curry favour with political power), opportunism (jumping onto the latest bandwagon) and apathy (withdrawing into a private religious sphere), we need to establish the integrity of our theological approach. This means that we need to gain clarity about theological method. To my mind, this can be done best by using the notion of praxis - the continuous and complex interplay between theory and practice, praying and working, doing and being. The nature of our theological praxis can be traced by asking at least the following seven questions: ${ }^{5}$

(a) Agency: Who am I? Who are we? Do we affirm our identity? Do we publish in our first languages?

(b) Contextual understanding: What is really going on here? What factors play a role?

(c) Ecclesial analysis: What has the church done about this in the past? What impact did it make and what image does it have in the community?

(d) Interpreting the Christian tradition: How do we re-read the bible and our confessions in and for this specific context with its problems?

(e) Discerning good strategies for creative action in the context: What can we $d o$ about this?

5 For more detail on this praxis approach to doing theology, see Kritzinger (2008) and Kritzinger and Saayman (2011). 
(f) Reflexivity: What do we learn from our past-from our failures, successes and silences?

(g) Spirituality: What faith experience or sense of God inspires and guides our actions? What is the depth dimension of our life that will take us into in-depth engagement with these issues and sustain us in doing so?

One of the urgent priorities for a theology that wishes to articulate a credible public voice is therefore the question of theological method. We need to develop the contextual-transformational methods of liberation theologies for the changed circumstances we face today. This involves integrating a hermeneutic of suspicion - which exposes what is unjust and alienatingwith a hermeneutic of trust - which builds community and mobilises people for a mission of liberating and transformative service. One of the reasons for our theological voicelessness is that we often feel inadequate in making connections between the realities around us, the faith community of which we are part, the projects we need to launch, the message of Scripture, and the spirituality that inspires us. The purpose of a praxis approach enables us to integrate these essential dimensions of transformative faith.

A praxis approach is inherently communal; it is not for lone individual thinkers or actors, so it can help us overcome our sense of inadequacy when we want to make public statements or launch projects, but are not sure if we know enough about the context we wish to address, whether it be the South African economy or the situation in Palestine. So the second theological move we need to make is from a mono-disciplinary to a multi-disciplinary approach. If we as theologians want to speak and act with credibility in public, we need to learn how to collaborate with experts in other disciplines and fields of expertise. What we need urgently is joint think-tanks of theologians and experts in medicine, economics, biology, education, psychology and other disciplines who are committed to a transformative vision for society. We are not going to overcome our "inferiority voicelessness" if we continue to act in isolation as theologians. We have a contribution to make, but along with interlocutors from other specialised backgrounds - and also from among poor and marginalised communities - in think-tanks and task teams that are committed to embodying the liberating message of the reign of God in concrete situations. Together we can read the signs of the times with greater insight and discernment, and learn how to harness and mobilise the positive cultural resources from all South Africa's communities in the interest of justice, freedom and compassion.

\section{Developing concrete strategies}

To give some concrete shape to the ideas I have been developing in this paper, let me now focus on five areas of challenge for which we need to develop strategies to help us overcome our voicelessness. 


\subsection{Overcoming our voicelessness by loosening our own tongues}

To overcome voicelessness means to find your own voice. That requires identity strategies, in other words, processes and structures that help us to stand tall and confident, without being arrogant or superior. This has to do, among others, with cultural and linguistic self-affirmation, in other words with first-language theologising. Kwame Bediako, who referred to this as "vernacular theologising", strongly encouraged it in his publications and in the programmes of the Akrofi-Christaller Institute of Theology, Mission and Culture in Ghana (see for example Bediako 1996).

It seems unrealistic and counter-productive, however, to propagate first-language theologising in Africa (or elsewhere) to the exclusion of English. Multilingual theological competence (or at least bilingual competence) is what is called for, so that theologians and Christian communities may learn how to both "affirm their roots" and "spread their wings" (see Kritzinger 2002). One set of strategies to achieve this is a three-phase (or "sandwich") approach in which a diverse group of people start their interaction in a plenary session where the topic is introduced, then divide into subgroups characterised by culture, race, language or gender - in which participants examine the topic in terms of their distinctive experience and identities - and then conclude the interaction with a final plenary session in which they share their insights and develop common understandings. By moving back and forth between what they have in common and what makes them different, an ethos of mutuality and reciprocity can gradually grow, thus creating an intercultural space to counteract and overcome tendencies towards ethnocentrism and Afro-phobia (as well as other exclusionist and oppressive ways of life). Such an approach can nurture a society in which "the dignity of difference" is acknowledged and affirmed, while we learn how to "build a home together" (Sacks 2007).

Such identity strategies can instil both assertiveness and openness in our communities, enabling us to overcome the paralysing effect of "inferiority voicelessness", as pointed out above. Theologically speaking, it is the work of the Holy Spirit to create community and to loosen our tongues. Guided by the Spirit we should lead Christian communities into the truth by nurturing such inclusive identity strategies.

\subsection{Overcoming voicelessness by drinking from our own wells}

In addition to the identity strategies alluded to above, we need theological research strategies to overcome our voicelessness. In too many ways is our theological agenda determined by priorities and standards set by the global North. We need projects to unlock and mobilise African cultural, religious and theological resources. For the identity strategies described above to work well, members of each participating group need to affirm their own roots by digging into their own resources. We need to explore the 
indigenous faith-and-knowledge systems embodied in the proverbs, idioms, rituals, songs and prayers of our communities and bring these to bear on the theological and political questions we are grappling with. The wisdom and humanity of these cultural-religious resources are essential to informing and directing our praxis if we are to make significant contributions to the intercultural plenary sessions of the strategies mentioned above. For too long has the only translation done in Christian and theological circles been from Hebrew, Greek, English, German and French into various African languages. What we need now is a free flow of translations back and forth across the intercultural space opened up by the identity strategies suggested above.

One should not be naïve about the process, however. There are power differences between languages in South Africa, owing to the colonial policies that flourished on othering and excluding indigenous or vernacular languages to the benefit of Dutch and English (and later English and Afrikaans). It was decades of government and private sector funding for academic projects like Afrikaans universities, research institutes and cultural organisations that enabled Afrikaans to develop the vocabulary that has made it a respected intellectual vehicle for research and public discourse. The numerous Afrikaans and Afrikaans-English dictionaries bear testimony to this significant investment of money and intellectual endeavour over decades that has made Afrikaans what it is today.

The urgent challenge of our time is to put as much (if not more) energy and money into research to produce multilingual and intercultural dictionaries or resource books to stimulate intellectual exploration and experimentation within - and between-cultural-linguistic communities. I cannot think of a more helpful and urgent project for a community of theologians than this. Such intercultural theological resources could be used in ministerial formation, pastoral practice and theological research to contribute to more creative interaction and collaboration between churches and communities. We will overcome our theological voicelessness when we collaborate in projects that open up intercultural sharing and understanding, not in order to find one mighty united voice but a multiplicity of softer, humbler voices reaching out to each other across chasms of misunderstanding, exclusion and oppression. Perhaps the notion of a "second naiveté" (Ricœur 1967:349) could be applied in an adapted way here: what needs to emerge from our present voicelessness is a "second voicefulness", which is not the same as the naïve and confident voice of a strident prophetic critique. A humbler and more chastened theological voice is appropriate in a post-colonial setting where the self-sure theological arguments for and against apartheid no longer inspire and mobilise faith communities as they used to. This does not mean a retreat into relativism or silence, but an advance into a more inclusive and humanising engagement with those who are different from us. 


\subsection{Overcoming our voicelessness by marching to a different drum}

What I have said in the previous two points can be taken to mean a retreat from politics into a "safe" cultural or intercultural sphere of engagement. That is not what I mean. Along with the identity strategies and research strategies that I have explained, we need new political strategies in (South) Africa. In this regard, I take my cue from Emmanuel Katongole in his book The sacrifice of Africa (2010). Following Stanley Hauerwas's narrative approach, Katongole asks what the "foundational story" is of the state in Africa. He concludes that in the aftermath of colonialism the political actors have changed, but the exploitative and abusive script of the colonial state has remained. What we need to do now, Katongole argues, is to write a new script for African politics that can lead us out of the destructive colonial legacy. To begin to rewrite that script he examines four creative African initiatives (two men and two women) who dared to incarnate and relocate themselves into the lives of suffering people. What is significant is that he does not expect much good from the African state and instead explores the courageous service of Christian leaders working "outside the camp". While they have clearly articulated theological voices, the striking thing about Katongole's role models is their compassionate behaviour towards and courageous advocacy on behalf of the exploited and excluded, specifically in contexts of rampant and destructive ethnocentrism or genocide.

The state and multiparty democracy in African countries are indeed in trouble. To find a new theological voice in this context that can speak a liberating and healing word to politics, we need to consider seriously changing our focus from party politics to the arena of civil society. This concept does have its problems, but Sacks (2007:110) argues in favour of a social covenant that can create a society:

Social contract creates a state; social covenant creates a society.

Social contract is about power and how it is to be handled within a political framework. Social covenant is about how people live together despite their differences. Social contract is about government. Social covenant is about coexistence. Social contract is about laws and their enforcement. Social covenant is about the values we share. Social contract is about the use of potentially coercive force. Social covenant is about moral commitments, the values we share and the ideals that inspire us to work together for the sake of the common good.

Sacks' voice is different from that of Katongole, but both of them emphasise the important role of religion in building a human society based on values of justice, compassion and freedom. There is always the temptation to be so attracted by political power that we sycophantically ingratiate ourselves with (party) politicians as a means of finding social legitimacy and recognition. That 
is a sure way to lose our theological voices and therefore a temptation we need to resist resolutely if our voices are to re-emerge as distinct from political correctness or the whitewashing of party policies and ideologies:

[B]ecause they have misled my people, saying, "Peace," when there is no peace; and because, when the people build a wall, these prophets smear whitewash on it. Say to those who smear whitewash on it that it shall fall. There will be a deluge of rain, great hailstones will fall, and a stormy wind will break out. When the wall falls, will it not be said to you, "Where is the whitewash you smeared on it?" (Ezek. 13:10-12).

If we are to recover our theological voices, we will need to assert our independence from party political ideologies and affirm the integrity of our religious vision of a good society. Speaking with Katongole, we need to receive courage from the Holy Spirit to relocate from our positions of privilege and comfort in order to incarnate ourselves among the lost and the excluded.

\subsection{Overcoming voicelessness in the academy by giving a reasonable account of the hope in us}

What is Christian theology doing at a state-subsidised university? This question has been asked in different ways by different role-players in South Africa after the advent of democracy. A good example is Krüger (1994:16):

Non-Christians had (and still have) the dubious privilege of having their taxes funneled into faculties and departments aimed at converting them from their own religion. This sounds like a sick joke. It is, to put it bluntly, a monopolistic and discriminatory arrangement.

This is an important ethical question, as we reflect on the role of theological voices in public life. It is not possible to address all the dimensions of Krüger's statement, ${ }^{6}$ but we must give a rational and moral apologia for what Christian theology is doing at a state university in South Africa after 1994. If we are to recover from our theological voicelessness a key question will be what our role should be in the academy, where public leaders are developed.

My approach to this question would be to say that as Christian theologians we should not demand it as a right to offer theology on a university campus, but to argue that it is wiser for a society to create this open intellectual space for Christian theology - and for the theologies of other faiths - than to banish them to seminaries and bible schools. It is also wiser to allow the "committed" study of Christian, Jewish, Hindu and Muslim theologies at universities than to change all the intellectual reflection on religions into a religious studies approach, whether of a comparative, phenomenological or other stamp. Let me argue these two points separately.

6 See Kritzinger (1995). 
Firstly, to ban all committed study of Christian (and other) theologies to private seminaries and colleges is to run the risk of removing theological reflection from the atmosphere of public intellectual debate and self-critical reflection, while exposing it to the danger of becoming more narrow and bigoted in its approach. The climate of critical enquiry and intellectual accountability on a university campus, where theological lecturers and students rub shoulders daily with colleagues from other disciplines and religions, nurtures a kind of theology and theologian that is more likely to adopt a tolerant and inclusive approach to social problems than the bigoted or Biblicist approaches often produced by private bible colleges. This is not to claim special privileges for the Christian faith; the same opportunities and privileges must be extended to other faith communities who wish to pursue committed theological reflection on their tradition and to train their religious leaders at state-funded universities. In this way, one has a better chance of preventing the Talibanisation of theology in private (and therefore publicly unaccountable) bible schools or seminaries.

In order to counter the claim that theology courses at state universities are training Christian students to "convert" others to their faith, the academic offerings of theologians should be opened to public scrutiny and transformed (where necessary) so that the purpose and outcomes of each module may be scrutinised, and it can become clear what actual effect it is having on students. In addition, it needs to be said that many churches and other religious groups are evangelising in communities and preaching their messages of repentance and renewal. They are preaching their messages, doing charity, offering scholarships to needy students, etc., often with little or no accountability structure or self-critical reflection on what they are doing. It is far healthier for society as a whole when future religious leaders receive their intellectual formation in an academic space where they can learn to think self-critically about their practices.

Secondly, to insist that only a non-committed religious studies approach may be allowed at state-subsidised universities also represents an unwise narrowing of public intellectual spaces. It is politically correct to do so, in terms of European and North American academic traditions, but it is ironic that some African intellectuals who emphasise Indigenous Knowledge Systems characterised by African holism and communalism, also support a totally un-African separation between faith and knowledge, facts and values, on university campuses. I hope that the movement called the African Renaissance, within the economic ascendancy of Asian, Latin American and African countries in the world economy, will create the space for intellectuals in the global South to negotiate new academic cultures in which religious values (and the critical study of religion) are no longer privatised or commoditised, but seen as an integral part of the empowerment and development agenda. In this way religion can be 
harnessed and engaged as a critically important dimension of public life (or "civil society") that contributes constructively to addressing social ills and helping to counter some of the negative and destructive discourses that are circulating in relation to issues like poverty, HIV, patriarchy and racism. There should be space for religions to be studied phenomenologically, historically and comparatively at universities, but there should also be the possibility of studying religious traditions from within, from a committed faith position, with the understanding that the theological study of a religion should not be done from a "conversionist" perspective, but in a way that fosters interreligious respect and collaboration, while remaining faithful to and recognisably authentic within that particular religious tradition. A "roots and wings" approach (see Kritzinger 2002:145 f) needs to be followed. This means that the affirmation of distinct religious and cultural identities-and the resultant confidence to bear respectful witness to others-goes hand in hand with the free and confident exploration of the views of others. In conclusion, the positivist notion that religious studies produces unbiased and objective knowledge of different religions, whereas theology produces only biased and one-sided knowledge of only one religion should be dispelled. The knowledge of religion(s) is never neutral; what matters is that we should admit our biases, examine them, and "discipline" them so that they do not unduly affect (or distort) our observation or systematic, critical reflection on the dimensions of religion that we are exploring, whether they be scriptures, rituals or other faith practices. Such a study of religion(s) should motivate us to be creatively faithful to the tradition in which we stand and to engage in intercultural and interreligious dialogue and cooperation.

Christian theology can be defined as critical-creative reflection on Christian practices in context. It does not incite Christians to "convert" people of other faiths to Christianity, but starts from the empirical observation that Christian communities (like Muslim, Buddhist and neo-Hindu communities) are busy spreading their faith to others. The role of theological reflection is to reflect critically on such mission practices to ensure that they are faithful to the spirit of the Christian movement and do not abuse power, or coerce people in the process. Rather than encouraging Christians to "convert" people of other faiths, the study of missiology at university faculties of theology more often than not has a sobering and clarifying effect on mission practices. The institutions that are far more likely to "incite" Christians to insensitive and aggressive evangelism are private bible schools and seminaries. The discipline of missiology is often singled out (by scholars of other disciplines and by fellow theologians) as the prime culprit in this negative role of theology at universities, but such criticism is often uninformed and based on prejudice. The undergraduate modules offered by the discipline group of missiology at the University of 
South Africa could serve as an example here. The six undergraduate modules taught are

(a) The dynamics of mission;

(b) Youth work in communities;

(c) Intercultural Christian communication;

(d) The dynamics of interreligious encounter;

(e) Christian action for anti-racism and reconciliation; and

(f) Integrated theological praxis (capstone module).

Anybody who goes to the trouble to look at the stated outcomes or learning strategies adopted in these modules will have to admit that these modules are intended to motivate students to action that is not only faithful to the Christian tradition, but also sensitive and deeply respectful to people of other faiths and committed to enhancing the lives of those who suffer and are excluded from dominant political, economic and social practices. Such theology brings religious leaders into an academic space where they can learn to think self-critically about their practices and begin to refocus them.

I do not argue that the teaching of theology at state-funded universities should be taken for granted. I do not claim this with arrogance as some kind of right. Theologians in these positions should show through their research contributions and collegiality that they have a contribution to make towards the common good. The wisdom of 1 Peter 3:15 should guide us in this: "Always be ready to make your defense to anyone who demands from you an accounting for the hope that is in you; yet do it with gentleness and reverence." The voice that we need to recover in the academy to overcome our voicelessness should not be shrill and trident.

\subsection{Overcoming voicelessness through worship}

To conclude, it is important that we as theologians also employ liturgical strategies to overcome our voicelessness, in addition to the identity, research, political and academic strategies spelled out above. There is a sense in which we need to learn voicelessness (in a positive sense) in worship. The type of voicelessness that I identified earlier as awe and admiration for beauty is an essential dimension of religious faith, at least in the Judeo-Christian-Islamic trajectory. As the prophet Habakkuk (2:20) said in his critique of human idolatry and trust in human authority: "[T]he LORD is in his holy temple; let all the earth keep silence before him!" This is similar to the message of that well-known Christian "freedom song":

Thula sizwe, ungabo khala [Be quiet, people, do not cry;] uJehovah wakho uzokunqobela [Your Jehovah will conquer for you]. 
These words come from Exodus 14, being the encouraging words of Moses to the frightened group of slaves on their way out of Egypt, before the crossing of the Red Sea, with Pharaoh's forces closing in on them from behind. There was a wrong kind of voice: a fearful expression of despair, which included the rejection of Moses and God. That is different from lament, in which a believer wrestles with God in passionate engagement: "My God, my God, why have you forsaken me?" (Ps. 22) or "How long, O LORD? Will you forget me for ever?" (Ps. 13). The biblical phrases of lifting up, "lift up your hearts", "lift up your hands", "lift up your soul", "lift up your eyes", all testify to a sense of transcendence and humble trust that is expressed in worship. A chastened and renewed voice that follows on and responds to a hearing of God's voice; a new voice and a new song that flows from silent awe and admiration at who God is and what God does in history.

Theology cannot separate itself from worship; it cannot exist apart from it. Overcoming theological voicelessness is in a fundamental sense a matter of worship and spirituality, of learning to put all empires and rulers in their proper place by acknowledging who really has the last word. There are few things that are as dangerous to and as undermining of injustice and oppressive authority as the act of faith that overcomes the fear, guilt, shame or nepotism of voicelessness by learning to worship the living God.

\section{References}

Bediako, K. 1996. Christianity in Africa: The renewal of a non-Western tradition. Edinburgh: Edinburgh University Press.

Bosch, DJ. 1991. Transforming Mission: Paradigm shifts in theology of mission. Maryknoll: Orbis.

Brown, D. 2003. The Da Vinci code. New York: Doubleday.

Câmara, D.H. 2012 [1972]. A covenant that deserves to crown your journey. http://courseweb.stthomas.edu/gwschlabach/docs/manitese1.htm [accessed 22 Nov. 2012].

Dawkins, R. 2006. The God delusion. London: Bantam Books.

Farley, W. 1990. Tragic vision and divine compassion: A contemporary theodicy. Louisville, Ky.: Westminster/John Knox.

Farlex. N.d. Voicelessness. http://www.thefreedictionary.com/voicelessness [accessed 22 Nov. 2012].

Fukuyama, F. 1992. The end of history and the last man. New York: Free Press.

Katongole, E. 2010. The sacrifice of Africa: A political theology for Africa. Grand Rapids, Mich.: Eerdmans.

Kritzinger, J.N.J. 1995. Studying religious communities as agents of change: An agenda for missiology. Missionalia 23(3), November:366-396. 
Kritzinger, J.N.J. 2002. A question of mission-A mission of questions. Missionalia 30(1), December:144-173.

Kritzinger, J.N.J. 2008. Faith to faith-Missiology as encounterology. Verbum et Ecclesia 29(3), November:764-790.

Kritzinger, J.N.J. and Saayman, W.A. 2011. David J. Bosch: Prophetic integrity, cruciform praxis. Pietermaritzburg: Cluster Publications.

Krüger, J.S. 1994. From one to many: The challenge of religious pluralism. The teaching of Christianity in state schools and universities in South Africa. Pretoria: C.B. Powell Bible Centre.

Newbigin, L. 1984. The other side of 1984: Questions for the churches. Geneva: WCC.

Newbigin, L. 1986. Foolishness to the Greeks: The gospel and Western culture. Geneva: WCC.

Newbigin, L. 1989. The gospel in a pluralist society. Grand Rapids: Eerdmans.

Ricœur, P. 1967. The symbolism of evil. New York: Harper \& Row.

Volf, M. 1996. Exclusion and embrace: A theological exploration of identity, otherness, and reconciliation. Nashville, Tenn.: Abingdon Press.

Sacks, J. 2007. The home we build together: Recreating society. London, New York: Continuum.

Swinton, J. 2006. Raging with compassion: Pastoral responses to the problem of evil. Grand Rapids, Mich.: Eerdmans.

Unisa (University of South Africa). 2011. Voice and voicelessness: Religious, ethical, political and theological perspectives on social discourses and praxis in the new millennium. http://www.unisa.ac.za/Default.asp? Cmd=ViewContent\&ContentID=26446 [accessed 23 Nov. 2012].

Van der Westhuizen, C. 2007. White power and the rise and fall of the National Party. Cape Town: Zebra Press.

Whitehead, E.E. and Whitehead, J.D. 1984. Seasons of strength: New visions of adult Christian maturing. Garden City, N.Y.: Doubleday. 